\title{
PEMBELAJARAN FISIKA BERBASIS INKUIRI TERBIMBING DENGAN MENGGUNAKAN LKS UNTUK MENINGKATKAN KETERAMPILAN BERPIKIR KRITIS DITINJAU DARI SIKAP ILMIAH SISWA MADRASAH ALIYAH QAMARUL HUDA BAGU LOMBOK TENGAH
}

\author{
Yuyu Sudarmini ${ }^{1)}$, Kosim $^{2)}$, Aos Santoso Hadiwijaya ${ }^{2)}$ \\ Program Studi Magister pendidikan IPA Program Pascasarjana IPA Universitas Mataram ${ }^{12}$ \\ MA Qamarul Huda Bagu Pringgarata Lombok Tengah ${ }^{1}$
}

yuyu_sudarmini@yahoo.co.id,kosimho@yahoo.com, aos_santosa@yahoo.com

\begin{abstract}
ABSTRAK
Penelitian ini bertujuan untuk: (1) Mengembangkan perangkat pembelajaran fisika berbasis inkuiri terbimbing dengan menggunakan LKS, (2) Mengetahui perbedaan peningkatan keterampilan berpikir kritis antara siswa yang mendapatkan pembelajaran fisika berbasis inkuiri terbimbing dengan mengunakan LKS dan siswa yang mendapatkan pembelajaran fisika secara konvensional, (3) Mengetahui perbedaan peningkatan keterampilan berpikir kritis antara siswa dengan sikap ilmiah tinggi dan siswa dengan sikap ilmiah rendah, (4) Mengetahui interaksi antara pembelajaran fisika (berbasis inkuiri terbimbing dengan menggunakan LKS dan secara konvensional) dan sikap ilmiah terhadap peningkatan keterampilan berpikir kritis siswa. Penelitian ini dilaksanakan dalam dua tahap yaitu: (1) penelitian pengembangan dengan menggunakan model pengembangan Dick and Carey, (2) penelitian eksperimen dengan desain faktorial 2x2. Populasi dalam penelitian eksperimen adalah siswa kelas XI IPA MA Qamarul Huda Bagu Lombok Tengah. Sampel penelitian terdiri dari dua kelas yang diambil secara simple random sampling. Pengumpulan data menggunakan angket untuk mengetahui sikap ilmiah siswa, dan tes untuk mengetahui skor keterampilan berpikir kritis siswa. Uji hipotesis untuk penelitian eksperimen menggunakan anava dua jalur dengan bantuan program SPSS pada taraf signifikansi $0,05 \quad(\alpha=5 \%)$. Hasil penelitian pengembangan yaitu diperoleh perangkat pembelajaran fisika berbasis inkuiri terbimbing dengan menggunakan LKS yang termasuk dalam kategori baik. Hasil penelitian eksperimen menunjukkan: 1) Terdapat perbedaan peningkatan keterampilan berpikir kritis antara siswa yang mendapatkan pembelajaran fisika berbasis inkuiri terbimbing dengan menggunakan LKS dan siswa yang mendapatkan pembelajaran fisika secara konvensional. Hal ini ditunjukkan dengan nilai $F_{\text {hitung }}=42,480$ lebih besar dari nilai $F_{\text {tabel }}=4,11$ dan nilai sig=0,000 lebih kecil dari 0,05.2) Terdapat perbedaan peningkatan keterampilan berpikir kritis antara siswa dengan sikap ilmiah tinggi dan siswa dengan sikap ilmiah rendah. Hal ini ditunjukkan dengan nilai $F_{\text {hitung }}=13,150$ lebih besar dari nilai $F_{\text {tabel }}=4,11$ dan nilai sig=0,001 lebih kecil dari 0,05. 3) Tidak terdapat interaksi antara pembelajaran fisika (berbasis inkuiri terbimbing dengan menggunakan LKS dan secara konvensional) dan sikap ilmiah terhadap peningkatan keterampilan berpikir kritis. Hal ini ditunjukkan dengan nilai $F_{\text {hitung }}=1,277$ lebih kecil dari nilai $\mathrm{F}_{\text {tabel }}=4,11$ dan nilai sig=0,265 lebih besar dari 0,05. pembelajaran fisika berbasis inkuiri terbimbing dengan menggunakan LKS diharapkan dapat dikombinasikan dengan model pembelajaran lain agar dapat meningkatkan keterampilan berpikir kritis lebih optimal terutama untuk materi fisika yang bersifat abstrak.
\end{abstract}

Kata kunci : Inkuiri terbimbing, LKS, sikap ilmiah, keterampilan berpikir kritis. 


\begin{abstract}
This research aimed at 1). Developing learning design of guided inquiry based physics learning using student worksheet. 2). Knowing the difference of improvement of the critical thinking between students those who learned using guided inquiry based physics learning and those who learned physics conventionally. 3). Knowing the difference of improvement of the critical thinking between students with a highly scientific attitude and those with a low one. 4) Knowing the interaction between learning physics and scientific attitude toward the improvement of students' critical thinking skill. The research was conducted through two steps, namely: 1) Development research using Dick's and Carey's development model, 2) Experimental research using 2x2 factorial design. The population of this research was the students of MA Qamarul Huda Bagu, central Lombok, year eleven. The sample of the research consisted of 2 classes taken by simple random sampling technique. Data collection using questioner to know the students' scientific attitude, and test to know the students' critical thinking skill score. Hypothetical test for experimental research used two path ANAVA by using SPSS. The result of development research was yielded a good learning equipment of the guided inquiry based physics learning using student worksheet. The experimental research showed that: 1) There was difference of improvement of critical thinking skill between the students who got a guided inquiry physics learning using student worksheet and those who got conventional learning. This was shown by value of $F_{\text {test }}=42,480$, was higher than that of $F_{\text {table }}=4,11$, and the value of sig=000 was lower than 0,$05 ; 2$ ) There was difference of improvement of critical thinking skill between the students with a high scientific attitude and those with a low one. This was shown by value of $F_{\text {test }}=13,150$, was higher than that of $F_{\text {table }}=4,11$, and the value of sig $=0,001$ was lower than 0,$05 ; 3)$. There was no interaction between the physics learning (guided inquiry based using student worksheet and that of conventionally) and scientific attitude towards the improvement of critical thinking skill. This was shown by value of $F_{\text {test }}=1,277$ was lower than that of $F_{\text {table }}=4,11$ and value of sig $=0,265$ was higher than 0,05 . It was expected that the guided inquiry based physics learning using student worksheet was combined with other learning models to enhance critical thinking skill more optimal mainly for the abstract materials of physics.
\end{abstract}

Key word: guided inquiry, student worksheet, scientific attitude, critical thinking skill,

\title{
Pendahuluan
}

Sains merupakan cara mencari tahu tentang alam secara sistematis untuk menguasai pengetahuan, fakta-fakta, konsep-konsep, prinsip-prinsip, proses penemuan, dan memiliki sikap ilmiah. Pendidikan sains bermanfaat bagi siswa untuk mempelajari diri sendiri dan alam sekitar, serta dapat mengembangkan kompetensi agar siswa mampu menjelajahi dan memahami alam sekitar secara ilmiah (Depdiknas, 2008).

IPA merupakan bagian dari sains, menurut peraturan Menteri Pendidikan Nasional Republik Indonesia No 22 Tahun 2006 menyatakan bahwa tujuan pembelajaran IPA di sekolah menengah adalah agar siswa berkompeten untuk melakukan metode ilmiah untuk menyelesaikan suatu masalah, menguasai konsep IPA dan mengembangkan kemampuan berpikir kritis (Badan Standar Nasional Pendidikan, 2006). 
Menurut kurikulum KTSP, tujuan pembelajaran fisika SMA sebagai bagian dari IPA adalah agar siswa dapat memahami konsep-konsep fisika dan mampu menggunakan metode ilmiah yang didasari oleh sikap ilmiah untuk memecahkan masalah yang dihadapinya. Jadi pembelajaran fisika yang diharapkan berlangsung di sekolah adalah pembelajaran yang sesuai dengan tujuan pembelajaran fisika itu sendiri yakni berlangsungya pembelajaran yang didasarkan pada prinsip-prinsip ilmiah baik sikap ilmiah, proses ilmiah maupun produk ilmiah.

Tatang (2008) mengungkapkan bahwa dalam pembelajaran hendaknya guru membuat bahan ajar atau perangkat pembelajaran yang memberikan kesempatan pada siswa untuk untuk berkembangnya: (1) Kemampuan mengkonstruksi konsep dan teorema berdasarkan pada pengalaman dan pengetahuan yang sudah dimilikinya; (2) Kemampuan berpikir tingkat tinggi (seperti kemampuan berpikir kritis dan kreatif) melalui soal-soal (pertanyaan-pertanyaan) pemecahan masalah; (3) Kemampuan berkomunikasi dan berinteraksi (menghargai dan memahami pendapat yang berbeda serta saling menyumbang ide) melalaui kerja kelompok; dan (4) Sikap kerja keras, ulet, disiplin, jujur, serta motif berprestasi.

Dalam pembelajaran yang menuntut kegiatan eksperimen pada umumnya diperlukan perangkat pendukung, salah satunya yaitu lembar kerja siswa (LKS), karena LKS sangat baik digunakan untuk meningkatkan peserta didik dalam belajar, baik dipergunakan dalam penerapan metode terbimbing maupun memberikan latihan pengembangan. Seperti diungkapkan oleh Sunyoto dan Maryatun (2006), LKS bertujuan untuk menemukan konsep atau prinsip dan aplikasi konsep atau prinsip, tetapi kenyataan yang terjadi menunjukkan bahwa LKS yang digunakan dalam pembelajaran pada umumnya hanya berisi ringkasan materi, latihan soal atau berisi petunjuk praktikum yang tidak menggali keterampilan berpikir tingkat tinggi, salah satunya adalah keterampilan berpikir kritis. LKS seperti ini kurang memberikan pengalaman belajar dan tidak dapat melatih keterampilan berpikir kritis secara optimal. Hal ini sejalan dengan ungkapan Marsigit dalam Taufik (2011) yang menyatakan bahwa LKS yang ada saat ini umumnya berisi ringkasan materi dan latihan soal, tidak memberikan pengalaman meningkatkan keterampilan berpikir kritis. Oleh karena itu, peneliti mencoba menyusun suatu LKS yang berisi pertanyaan-pertanyaan penuntun yang tepat sehingga dapat menggali dan mengkondisikan siswa agar kompetensi keterampilan berpikir kritis dapat tercapai melalui tahapan-tahapan inkuiri. 
Berdasarkan studi literatur dan hasil pengamatan peneliti bahwa pembelajaran fisika di sekolah pada umumnya lebih menekankan aspek kognitif. Kegiatan hafalan mendominasi untuk menguasai ilmu pengetahuan, tidak mengembangkan sikap ilmiah dan keterampilan berpikir yang dapat memberikan pengalaman nyata dan eksperimen aktif. Menurut Redhana dkk, (2008), pembelajaran saat ini masih cenderung mengkondisikan siswa ke dalam belajar hafalan (rote learning). Masih banyak siswa yang hanya menghafal konsep-konsep, prinsip-prinsip atau rumus, mencatat apa yang diceramahkan guru, dan bersifat pasif. Kondisi pembelajaran seperti ini mengakibatkan siswa sangat mudah lupa materi yang telah dipelajari sebelumnya. Diungkapkan pula oleh Bassham, et al dalam (Redhana dkk, 2008) bahwa dalam pembelajaran kebanyakkan sekolah cenderung menekankan keterampilan berpikir tingkat rendah. Siswa menyerap informasi secara pasif dan kemudian mengingatnya pada saat mengikuti tes. Kondisi pembelajaran seperti ini disebabkan karena penggunaan model, strategi maupun perangkat pembelajaran yang kurang tepat, tidak bervariasi dan tidak berpusat pada siswa. Redhana dalam (Suardana, 2008), mengungkapkan bahwa kebanyakan guru-guru menggunakan metode informasi dengan sesekali menggunakan metode tanya jawab kemudian diikuti dengan latihan soal yang diambilkan pada bagian akhir dari suatu bab buku, di mana soal-soal ini merupakan soa-soal well-structured. Selain itu model dan strategi pembelajaran yang digunakan tidak didukung dengan perangkat pembelajaran yang tepat sehingga tidak dapat melatih kemampuan siswa dalam berpikir.

Lawson dalam (Suardana, 2008), mengungkapkan bahwa siswa dapat ditingkatkan keterampilan berpikir kritisnya jika kurikulum didesain secara eksplisit untuk meningkatkan keterampilan berpikir kritis melalui urutan pembelajaran inkuiri dari konsep yang dipahami dan dapat diamati (observable) menuju konsep yang tidak dipahami dan abstrak. Lipmen dalam (Suardana, 2008), menyatakan bahwa pengembangan keterampilan berpikir kritis dapat dilakukan dengan mengkondisikan pembelajaran sedemikian rupa sehingga siswa memperoleh pengalaman-pengalaman dalam pengembangan keterampilan berpikir kritis. Salah satu pembelajaran yang dapat melatih keterampilan berpikir kritis adalah pembelajaran inkuiri karena pembelajaran inkuiri memiliki tahapantahapan yang mengkondisikan siswa untuk dapat melatih keterampilan berpikir, salah satunya keterampilan berpikir kritis Oleh karena itu, diperlukan suatu pembelajaran yang didukung dengan perangkat pembelajaran yang tepat yang dapat mengkondisikan siswa 
sedemikain rupa sehingga dapat melatih kemampuan berpikir siswa terutama kemampuan berpikir tingkat tinggi.

Salah satu cara untuk melatih keterampilan berpikir kritis adalah dengan melakukan pembelajaran fisika berbasis inkuiri terbimbing dengan menggunakan LKS (Lembar Kerja Siswa). Bimbingan guru dalam pembelajaran inkuiri terbimbing ini dibuat secara tertulis yang disajikan dalam LKS berstruktur untuk membantu siswa menemukan suatu konsep. LKS yang dirancang sedemikian rupa agar sesuai dengan tahapan dalam pembelajaran inkuiri sehingga dapat menggali dan melatih keterampilan berpikir kritis.

Pembelajaran fisika berbasis inkuiri terbimbing dengan menggunakan LKS diharapkan dapat meningkatkan keterampilan berpikir kritis ditinjau dari sikap ilmiah siswa, oleh karena itu tujuan dalam penelitian ini adalah:

(1) Mengembangkan perangkat pembelajaran fisika berbasis inkuiri terbimbing dengan menggunakan LKS, (2) Mengetahui perbedaan peningkatan keterampilan berpikir kritis antara siswa yang mendapatkan pembelajaran fisika berbasis inkuiri terbimbing dengan mengunakan LKS dan siswa yang mendapatkan pembelajaran fisika secara konvensional, (3) Mengetahui perbedaan peningkatan keterampilan berpikir kritis antara siswa dengan sikap ilmiah tinggi dan siswa dengan sikap ilmiah rendah, (4) Mengetahui interaksi antara pembelajaran fisika (berbasis inkuiri terbimbing dengan menggunakan LKS dan secara konvensional) dan sikap ilmiah terhadap peningkatan keterampilan berpikir kritis siswa.

\section{METODE PENELITIAN}

Penelitian ini merupakan penelitian Education Research and Development yang terdiri dari dua bagian yaitu, penelitian pengembangan dan penelitian eksperimen. Penelitian pengembangan menggunakan model Dick and Carey. Penelitian eksperimen menggunakan desain faktorial 2x2 (Sugiyono, 2010).

Pengembangan dalam penelitian ini bertujuan untuk mengembangkan perangkat pembelajaran berupa LKS, Silabus, RPP, angket sikap ilmiah dan tes keterampilan berpikir kritis. Penelitian eksperimen bertujuan untuk mengetahui implementasi hasil pengembangan yang telah dilakukan.

Populasi dalam penelitian eksperimen adalah siswa kelas XI IPA MA Qamarul Huda Bagu Lombok Tengah. Sampel penelitian diambil secara simple random sampling dan diperoleh kelas XI IPA 1 sebagai kelas eksperimen yang mendapatkan pembelajaran 
fisika berbasis inkuiri terbimbing dengan meggunakan LKS dan kelas XI IPA 2 sebagai kelas kontrol yang mendapatkan pembelajaran fisika secara konvensional.

Variabel penelitian ini terdiri dari variabel bebas, variabel terikat dan variabel moderator. Variabel bebas yaitu pembelajaran fisika berbasis inkuiri terbimbing dengan menggunakan LKS dan pembelajaran fisika konvensional. Variabel terikat berupa keterampilan berpikir kritis dan variabel moderator berupa sikap ilmiah yang dikelompokkan menjadi dua yaitu sikap ilmiah tinggi dan sikap ilmiah rendah.

Pengumpulan data untuk mengetahui sikap ilmiah siswa dilakukan dengan menggunakan angket yang diberikan sebelum perlakuan baik pada kelas eksperimen maupun pada kelas kontrol. Angket sikap ilmiah terdiri dari pernyataan positip dan negatif dengan rentang skor antara 1 sampai 4. Berdasarkan analisis data diperoleh nilai rata-rata sikap ilmiah pada kelas eksperimen sebesar 56,55 dan 54,26 pada kelas kontrol. Kategori sikap ilmiah tinggi jika skor sikap ilmiah yang diperoleh lebih tinggi daripada nilai ratarata. Kategori sikap ilmiah rendah jika skor sikap ilmiah yang diperoleh lebih rendah dari pada nilai rata-rata.

Pengumpulan data untuk mengetahui skor keterampilan berpikir kritis siswa dilakukan dengan menggunakan tes yang terdiri dari 8 soal. Tes ini memuat 4 indikator ketrampilan berpikir kritis yang diberikan pada saat pretest dan postest, baik pada kelas eksperimen maupun pada kelas kontrol. Untuk mengetahui peningkatan keterampilan berpikir kritis, data dianalisis menggunakan rumus gain ternormalisasi. Hasil analisis peningkatan keterampilan berpikir kritis dikategorikan ke dalam kategori tinggi, sedang, dan rendah.

Uji hipotesis untuk penelitian eksperimen dilakukan secara kuantitatif dengan statistik inferensial menggunakan anava dua jalur dengan bantuan program SPSS pada taraf signifikansi $0,05(\alpha=5 \%)$. Sebelum dilakukan uji hipotesis dilakukan uji prasayarat yaitu uji normalitas untuk mengetahui apakah sebaran data sampel berdistribusi normal atau tidak dan uji homogenitas untuk mengetahui apakah data sampel berasal dari populasi yang terdistribusi dari variansi yang homogen atau tidak. Uji normalitas menggunakan uji Liliefors dengan $\alpha=5 \%$ dan uji homogenitas menggunakan uji $\mathrm{F}$ dengan $\alpha=5 \%$.

\section{Hasil dan Pembahasan}


LKS, Silabus, RPP, angket sikap ilmiah dan tes keterampilan berpikir kritis yang telah disusun oleh peneliti dijadikan sebagai draf awal (draf I) untuk kemudian dilakukan evaluasi formatif (uji coba perangkat pembelajaran) yang dilakukan melalui tiga tahap yaitu uji ahli, uji perorangan dan uji kelompok kecil. Hasil pengembangan berdasarkan revisi pada uji ahli dijadikan sebagai draf II. Hasil pengembangan berdasarkan revisi pada uji perorangan dijadikan sebagai draft III. Hasil pengembangan berdasarkan revisi pada uji kelompok kecil dijadikan sebagai draft IV yang digunakan sebagai perangkat baku yang siap digunakan dalam penelitian eksperimen.

Hasil penelitian pengembangan perangkat pembelajaran berupa LKS, Silabus, RPP, angket sikap ilmiah dan tes keterampilan berpikir kritis pada uji ahli sebagai berikut:

Tabel 1. Hasil validasi perangkat dan instrumen pada uji ahli

\begin{tabular}{llcc}
\hline No & \multicolumn{1}{c}{ Perangkat/Instrumen } & Persentase & Kategori \\
\hline 1 & LKS & $90 \%$ & Baik \\
2 & Silabus dan Rencana Pelaksanaan P & $89 \%$ & Baik \\
& embelajaran(RPP) & & \\
3 & Angket sikap ilmiah & $88 \%$ & Sangat baik \\
4 & Tes keterampilan berpikir kritis siswa & $85 \%$ & Baik \\
\hline
\end{tabular}

Hasil pengembangan LKS pada uji perorangan sebagai berikut:

Tabel 2. Hasil validasi instrumen LKS pada uji perorangan

\begin{tabular}{lrrc}
\hline & Perangkat/Instrumen & Persentase & Kategori \\
\hline LKS & $81 \%$ & Baik \\
\hline
\end{tabular}

Hasil pengembangan LKS pada uji kelompok kecil sebagai berikut:

Tabel 3. Hasil validasi instrumen LKS pada uji kelompok kecil

\begin{tabular}{lrrr}
\hline & Perangkat/Instrumen & Persentase & Kategori \\
\hline LKS & & $81 \%$ & Baik \\
\hline
\end{tabular}

Hasil uji ahli menunjukkan bahwa LKS, Silabus dan RPP, serta tes keterampilan berpikir kritis termasuk dalam kategori baik, sedangkan angket sikap ilmiah termasuk dalam kategori sangat baik. Pada uji perorangan dan uji kelompok kecil menunjukkan bahwa LKS termasuk dalam kategori baik.

Hasil penelitian eksperimen berupa data sikap ilmiah dan skor keterampilan berpikir kritis siswa sebagai berikut :

Tabel 4. Deskripsi data sikap ilmiah siswa

\begin{tabular}{llccccc}
\hline Kelas & $\begin{array}{c}\text { Sikap } \\
\text { ilmiah }\end{array}$ & $\begin{array}{c}\text { Jumlah } \\
\text { siswa }\end{array}$ & $\begin{array}{c}\text { Nilai } \\
\text { tertinggi }\end{array}$ & $\begin{array}{c}\text { Nilai } \\
\text { terendah }\end{array}$ & Mean & $\begin{array}{c}\text { Std.de } \\
\text { viasi }\end{array}$ \\
\hline Eksperimen & Tinggi & 9 & 61 & 58 & 56,55 & 3,15 \\
\multirow{3}{*}{ KontroL } & Rendah & 11 & 56 & 51 & & \\
& Tinggi & 13 & 61 & 55 & 54,26 & 4,44 \\
& Rendah & 10 & 54 & 44 & & \\
\hline
\end{tabular}


Berdasarkan tabel 4 diperoleh bahwa pada kelas eksperimen terdapat 9 siswa dengan kategori sikap ilmiah tinggi dan 11 siswa dengan kategori sikap ilmiah rendah, sedangkan pada kelas kontrol terdapat 13 siswa dengan kategori sikap ilmiah tinggi dan 10 siswa dengan kategori sikap ilmiah rendah,

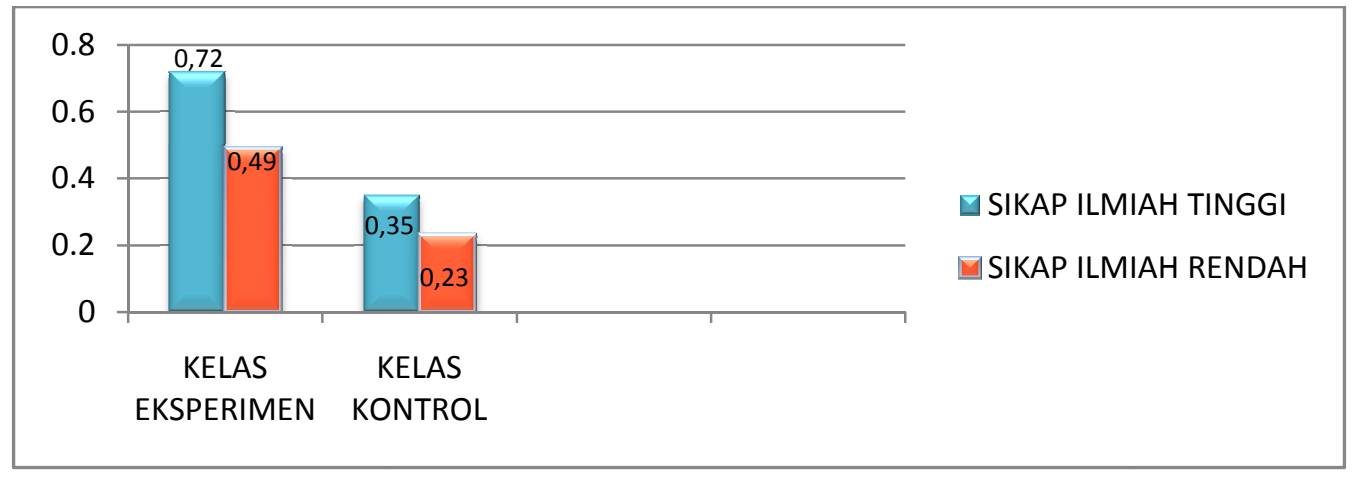

Gambar 1 Grafik perbandingan nilai rata-rata gain ternormalisasi keterampilan berpikir kritis

Berdasarkan gambar 1 menunjukkan bahwa rata-rata peningkatan (gain ternormalisasi) keterampilan berpikir kritis siswa yang mendapatkan pembelajaran fisika berbasis inkuiri terbimbing dengan menggunakan LKS lebih tinggi daripada rata-rata peningkatan (gain ternormalisasi) keterampilan berpikir kritis siswa yang mendapatkan pembelajaran fisika secara konvensional baik untuk kelompok siswa dengan sikap ilmiah tinggi maupun kelompok siswa dengan sikap ilmiah rendah. Hasil ini sejalan dengan penelitian Damanik, dan Bukit (2013) yang menyatakan bahwa kemampuan berpikir kritis pada sikap ilmiah siswa tinggi lebih baik dibandingkan dengan kemampuan berpikir kritis pada sikap ilmiah rendah.

Hasil pengujian normalitas dan homogenitas data peningkatan keterampilan berpikir kritis siswa pada keempat sampel sebagai berikut:

Tabel 5. Hasil pengujian normalitas data peningkatan keterampilan berpikir kritis.

\begin{tabular}{cccccc}
\hline Kelompok & $\mathrm{N}$ & $\alpha$ & $L_{o}$ & $L_{\text {tabel }}$ & Kesimpulan \\
\hline A1B1 & 9 & 0,05 & 0,1554 & 0,271 & Normal \\
A1B2 & 11 & 0,05 & 0,1630 & 0,249 & Normal \\
A2B1 & 13 & 0,05 & 0,1684 & 0,234 & Normal \\
A2B2 & 10 & 0,05 & 0,1948 & 0,258 & Normal \\
\hline
\end{tabular}

Keterangan:

A1B1: Kelompok siswa dengan sikap ilmiah tinggi yang mendapatkan perlakuan pembelajaran fisika berbasis inkuiri terbimbing dengan menggunakan LKS

A1B2 : Kelompok siswa dengan sikap ilmiah rendah yang mendapatkan perlakuan pembelajaran fisika berbasis inkuiri terbimbing dengan menggunakan LKS

A2B1 : Kelompok siswa dengan sikap ilmiah tinggi yang mendapatkan perlakuan pembelajaran fisika secara konvensional 
A2B2 : Kelompok siswa dengan sikap ilmiah rendah yang mendapatkan perlakuan pembelajaran fisika konvensional

Tabel 6. Hasil uji homogenitas varians data peningkatan keterampilan berpikir kritis

\begin{tabular}{|c|c|c|c|c|}
\hline & \multicolumn{4}{|c|}{ Kelompok } \\
\hline & A1B1 & A1B2 & A2B1 & $\mathrm{A} 2 \mathrm{~B} 2$ \\
\hline Varians & 0,0174 & 0,0308 & 0,0295 & 0,0159 \\
\hline Varians terbesar & \multicolumn{4}{|c|}{0,0308} \\
\hline Varians terkecil & \multicolumn{4}{|c|}{0,0159} \\
\hline$F_{\text {hitung }}$ & \multicolumn{4}{|c|}{1,93} \\
\hline$F_{\text {tabel }}(5 \%)$ & \multicolumn{4}{|c|}{3,13} \\
\hline Kesimpulan & \multicolumn{4}{|c|}{ Varian keempat sampel homogen } \\
\hline
\end{tabular}

Berdasarkan Tabel 5 dan Tabel 6 diperoleh bahwa data dari keempat sampel yang dianalisis berdistribusi normal dan varians data dari keempat sampel homogen. Hasil pengujian hipotesis ditunjukan pada Tabel 7 di bawah ini

Tabel. 7 Hasil uji anava dua jalur

Tests of Between-Subjects Effects

Dependent Variable: PENINGKATAN KETERAMPILAN BERPIKIR KRITIS

\begin{tabular}{|l|r|r|r|r|r|}
\hline Source & $\begin{array}{c}\text { Type III Sum } \\
\text { of Squares }\end{array}$ & df & Mean Square & \multicolumn{1}{c|}{ F } & \multicolumn{1}{c|}{ Sig. } \\
\hline Corrected Model & $1.256^{\mathrm{a}}$ & 3 & .419 & 17.289 & .000 \\
Intercept & 8.468 & 1 & 8.468 & 349.803 & .000 \\
PMBLJARN & 1.028 & 1 & 1.028 & 42.480 & .000 \\
SIKAP & .318 & 1 & .318 & 13.150 & .001 \\
PMBLJARN * SIKAP & .031 & 1 & .031 & 1.277 & .265 \\
Error & .944 & 39 & .024 & & \\
Total & 10.367 & 43 & & & \\
Corrected Total & 2.200 & 42 & & & \\
\hline
\end{tabular}

a. R Squared $=.571$ (Adjusted R Squared $=.538$ )

$\mathrm{F}_{\text {tabel }}\left(\mathrm{F}_{(1: 39)}\right)=4,11$ dan $\alpha=5 \%$

Interaksi yang terjadi antara pembelajaran fisika dan sikap ilmiah terhadap keterampilan berpikir kritis dapat digambarkan seperti di bawah ini. 


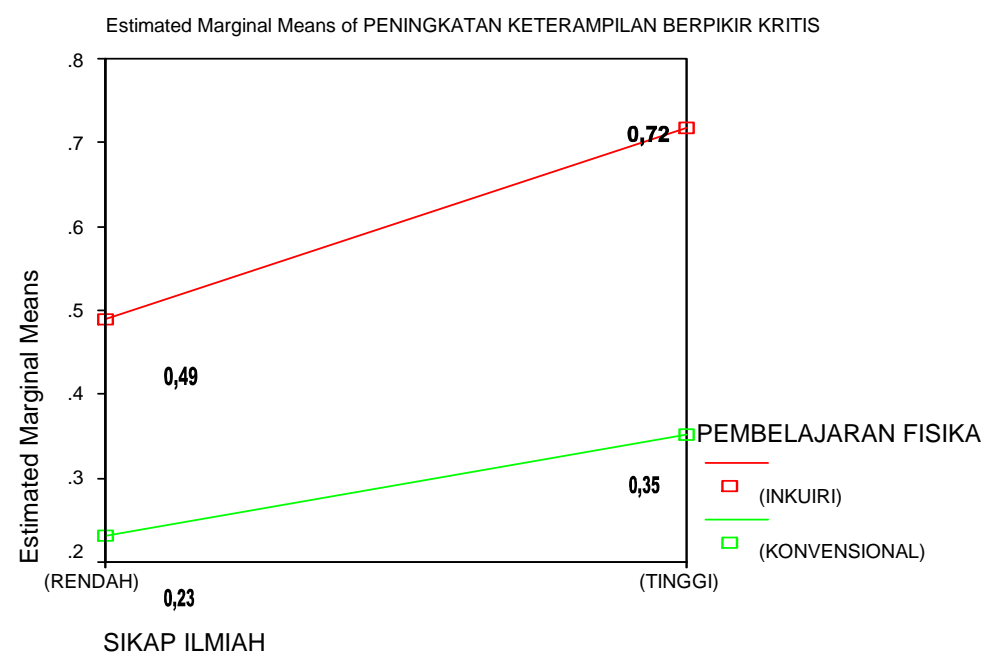

Gambar 2. Grafik interaksi antara pembelajaran fisika dan sikap ilmiah terhadap keterampilan berpikir kritis

Hasil uji hipotesis pertama seperti pada Tabel 7, diperoleh nilai sig.pembelajaran $=0,000$ lebih kecil dari 0,05 atau nilai $F_{\text {hitung }}=42,480$ lebih besar dari nilai $\mathrm{F}_{\text {tabel }}=4,11$. Hal ini menunjukkan bahwa terdapat perbedaan peningkatan keterampilan berpikir kritis yang signifikan antara siswa yang mendapatkan pembelajaran fisika berbasis inkuiri terbimbing dengan menggunakan LKS dan siswa yang mendapatkan pembelajaran fisika secara konvensional.

Kenyataan ini dikarenakan pembelajaran fisika berbasis inkuiri terbimbing dengan menggunakan LKS memberikan kesempatan kepada siswa untuk menemukan jawaban terhadap masalah yang dihadapkan kepadanya melalui tahapan mengamati kejadian sehari-hari yang berkaitan dengan materi dalam bentuk cerita yang disajikan dalam LKS, lalu merumuskan masalah dan hipotesis berdasarkan permasalahan yang ada dalam cerita yang disajikan pada LKS, kemudian merancang suatu eksperimen berdasarkan hipotesis yang dibuat, selanjutnya menganalisis data serta tahapan membuat kesimpulan untuk menjawab hipotesis yang telah diajukan. Pada saat siswa mengamati kejadian sehari hari yang disajikan dalam LKS, dapat melatih dan meningkatkan keterampilan berpikir kritis siswa dalam hal kemampuan menemukan dan menginformasikan permasalahan yang muncul. Lalu siswa diharapkan dapat memberikan alternatif pemecahan dari masalah tersebut. Pada saat siswa merancang dan melakukan percobaan, dapat melatih dan meningkatkan keterampilan berpikir kritis siswa dalam hal kemampuan merancang suatu eksperimen yang tepat untuk menjawab hipotesis yang telah diajukan. Sehingga siswa akan terbiasa untuk selalu membuktikan atau mencari tahu jawaban dari permasalahan yang muncul dengan suatu percobaan yang benar atau dengan studi literatur dari sumber yang tepat. Pada saat siswa menganalisis data dan menarik kesimpulan, dapat melatih dan meningkatkan keterampilan berpikir kritis siswa dalam hal kemampuan menyatakan 
tafsiran, menarik kesimpulan dan menerapkan konsep yang dapat diterima. Karena pada tahap akhir ini siswa dituntut untuk mampu menginterpretasi hasil analisis data percobaan yang diperoleh untuk menemukan suatu konsep. Lalu konsep yang telah diperoleh diharapkan dapat digunakan untuk memecahkan masalah yang diberikan dalam bentuk tes.

Hasil penelitian di atas sejalan dengan pernyataan Lawson (2001) dalam (Suardana, 2008) yang menyatakan bahwa siswa dapat ditingkatkan keterampilan berpikir kritisnya jika kurikulum didesain secara eksplisit untuk meningkatkan keterampilan berpikir kritis melalui urutan pembelajaran inkuiri dari konsep yang dipahami dan dapat diamati (observable) menuju konsep yang tidak dipahami dan abstrak. Hal yang senada juga diungkapkan oleh Lipmen (2003) dalam (Suardana, 2008), menurut Lipmen pengembangan keterampilan berpikir kritis siswa dapat dilakukan dengan mengkondisikan pembelajaran sedemikian rupa sehingga mereka memperoleh pengalaman-pengalaman dalam pengembangan keterampilan berpikir kritis.

Hasil uji hipotesis kedua seperti pada Tabel 7, diperoleh nilai sig.sikap $=0,001$ lebih kecil dari $0,05(0,001<0,05)$ atau nilai $F_{\text {hitung }}=13,150$ lebih besar dari nilai $\mathrm{F}_{\text {tabel }}=4,11$. Hal ini menunjukkan bahwa terdapat perbedaan peningkatan keterampilan berpikir kritis secara signifikan antara siswa dengan sikap ilmiah tinggi dan siswa dengan sikap ilmiah rendah.

Hal ini juga tampak pada gambar 1 yang menunjukkan bahwa bahwa siswa yang memiliki sikap ilmiah tinggi memiliki nilai rata-rata peningkatan keterampilan berpikir kritis lebih baik daripada siswa yang memiliki sikap ilmiah rendah baik pada kelas eksperimen maupun pada kelas kontrol. Hasil ini sejalan dengan penelitian Damanik, dan Bukit (2013) yang menyatakan bahwa kemampuan berpikir kritis pada sikap ilmiah siswa tinggi lebih baik dibandingkan dengan kemampuan berpikir kritis pada sikap ilmiah rendah.

Hal ini disebabkan karena siswa dengan sikap ilmiah tinggi memiliki rasa ingin tahu dan bertanggung jawab, sikap terbuka, kritis, cermat, teliti dan jujur, berpikir logis, rasional dan kreatif yang lebih baik (lebih tinggi) daripada siswa yang memiliki sikap ilmiah rendah, sementara sikap dan kemampuan tersebut sangat diperlukan untuk memecahkan permasalahan yang berkaitan dengan keterampilan berpikir kritis. Siswa yang memiliki sikap ilmiah tinggi akan lebih mudah dan lebih cepat memahami dan memecahkan permasalahan yang berkaitan dengan keterampilan berpikir kritis karena siswa yang memiliki sikap ilmiah tinggi akan mengunakan seluruh pengetahuanya untuk menemukan jawaban dari permasalahan yang ingin diketahui baik dengan cara membaca maupun bertanya kepada siapa saja yang mengetahui permasalahan tersebut. Sedangkan 
siswa yang memiliki sikap ilmiah rendah akan membutuhkan bimbingan yang lebih intens dan waktu yang lebih lama untuk memecahkan permasalah yang muncul, dalam hal ini permasalahan yang dimaksud berkaitan dengan keterampilan berpikir kritis.

Hasil uji hipotesis ketiga seperti pada Tabel 7, diperoleh nilai sig. sikap*pembelajaran $=0,265$ lebih besar dari $0,05(0,265>0,005)$ atau nilai $\mathrm{F}_{\text {hitung }}=1,277$ lebih kecil dari nilai $\mathrm{F}_{\text {tabel }}=4,11$. Hal ini menunjukkan tidak terdapat interaksi antara sikap ilmiah dan pembelajaran fisika (berbasis inkuiri terbimbing dengan menggunakan LKS dan pembelajaran secara konvensional) terhadap peningkatan keterampilan berpikir kritis siswa. Hasil ini juga dapat divisualisasikan secara grafis seperti pada gambar 2 yang menunjukkan tidak adanya perpotongan garis antara grafik pembelajaran fisika berbasis inkuiri terbimbing dengan menggunakan LKS dengan grafik pembelajaran fisika secara konvensional. Hasil ini menunjukkan bahwa antara pembelajaran fisika (berbasis inkuiri terbimbing dengan menggunakan LKS dan secara konvensional) dan sikap ilmiah tidak saling mempengaruhi. Hal ini berarti tidak ada kontribusi secara bersama-sama yang disumbangkan antara pembelajaran fisika (berbasisi inkuiri terbimbing dengan menggunakan LKS dan secara konvensional) dan sikap ilmiah untuk meningkatkan keterampilan berpikir kritis siswa. Siswa yang memiliki sikap ilmiah tinggi jika diberikan pembelajaran fisika (berbasis inkuiri terbimbing dengan menggunakan LKS dan secara konvensional) akan mempunyai peningkatan keterampilan berpikir kritis lebih tinggi dibandingkan siswa yang mempunyai sikap ilmiah rendah. Hal ini sejalan dengan hasil penelitian yang dilakukan oleh Damanik, dan Bukit (2013) yang mengungkapkan bahwa tidak terdapat interaksi antara model pembelajaran inquiry training dan direct instruction dengan sikap ilmiah siswa untuk meningkatkan kemampuan berpikir kritis.

Pembelajaran fisika yang diberikan kepada siswa dan sikap ilmiah merupakan dua hal yang berdiri sendiri sehingga apabila dipadukan secara bersama-sama maka tidak akan menimbulkan interaksi terhadap peningkatan keterampilan berpikir kritis siswa. Siswa yang memiliki sikap ilmiah tinggi jika diberikan perlakuan berupa pembelajaran fisika apapun baik berbasis inkuiri terbimbing dengan menggunakan LKS maupun secara konvensional, akan memiliki peningkatan keterampilan berpikir kritis yang lebih baik daripada siswa yang memiliki sikap ilmiah rendah. Hal ini seperti yang di ungkapkan oleh hasil penelitian Yuliani, dkk (2012) yang menyatakan bahwa tidak terdapat interaksi pembelajaran fisika pendekatan keterampilan proses menggunakan metode eksperimen dan demonstrasi dengan sikap ilmiah terhadap prestasi kongnitif dan afektif.

Oleh karena itu pembelajaran fisika berbasis inkuiri terbimbing dengan menggunakan LKS sangat tepat diterapkan dalam pembelajaran dalam rangka meningkatkan keterampilan berpikir kritis siswa. Karena selama proses pembelajaran 
berlangsung, tahapan-tahapan dalam pembelajaran inkuiri yang dilalui dapat melatih keterampilan berpikir kritis siswa. Dalam proses pembelajaran fisika berbasis inkuiri terbimbing dengan menggunakan LKS, siswa lebih banyak diberikan bimbingan dalam bentuk pertanyan-pertanyaan pengarah yang disajikan dalam LKS.

\section{Kesimpulan}

Berdasarkan hasil analisis data dan pembahasan terhadap hasil penelitian dapat disimpulkan bahwa: (1) Telah dikembangkan perangkat pembelajaran fisika berbasis inkuiri terbimbing dengan menggunakan LKS; (2) Terdapat perbedaan peningkatan keterampilan berpikir kritis antara siswa yang mendapatkan pembelajaran fisika berbasis inkuiri terbimbing dengan menggunakan LKS dan siswa yang mendapatkan pembelajaran fisika secara konvensional; (3) Terdapat perbedaan peningkatan keterampilan berpikir kritis antara siswa dengan sikap ilmiah tinggi dan siswa dengan sikap ilmiah rendah; (4) Tidak terdapat interaksi antara pembelajaran fisika (berbasis inkuiri terbimbing dengan menggunakan LKS dan secara konvensioanl) dan sikap ilmiah terhadap peningkatan keterampilan berpikir kritis siswa.

Mengacu pada pengalaman dan temuan selama penelitian, dapat direkomendasikan beberapa saran yaitu : (1) Diharapkan kepada guru mata pelajaran fisika khususnya untuk menerapkan pembelajaran fisika berbasis inkuiri terbimbing dengan menggunakan LKS dalam proses belajar mengajar karena dapat melatih dan meningkatkan kemampuan berpikir tingkat tinggi yaitu keterampilan berpikir kritis; (2) Guru diharapkan dapat menggunakan pembelajaran fisika berbasis inkuiri terbimbing dengan menggunakan LKS yang dikombinasikan dengan model pembelajaran lain agar dapat meningkatkan keterampilan berpikir kritis lebih optimal terutama untuk materi fisika yang bersifat abstrak; (3) Dengan adanya pembelajaran fisika berbasis inkuiri terbimbing dengan menggunakan LKS diharapkan dapat menjadi salah satu cara agar pembelajaran tidak lagi berpusat kepada guru melainkan berpusat kepada siswa, karena didalam pembelajaran ini siswa dituntut untuk menemukan sendiri konsep fisika dengan pertanyan-pertanyaan pengarah yang terdapat dalam LKS, sehinga guru hanya berperan sebagai fasilitator.

\section{Daftar Pustaka}

Amri, S dan Ahmadi, K. 2010. Proses Pembelajaran Kreatif dan Inovatif di dalam Kelas. Jakarta :Prestasi Pustaka Publisher. 
Badan Standar Nasional Pendidikan. 2006. Peraturan Meneteri Pendidikan Nasional Republik Indonesia No 22 Tahun 2006 Tentang Standdar Isi untuk

Satuan Pendidikan Dasar dan Menegah. Jakarta : BSNP.

Depdiknas, 2008. Garis-Garis Besar Program Pengajaran Sekolah Menengah atas. Jakarta: Departemen Pendidikan Nasional Republik Indonesia.

Damanik, D. P., dan Bukit, N. 2013. Anlisis kemamapuan berpikir kritis dan sikap ilmiah pada pembelajaran fisika menggunakan model pembelajaran inkuiri training dan direct instruction. Jurnal online pendidikan fisika .Universitas Negeri Medan. http://dikfispasca.org/wp-content/uploads/ 2013/08/3.-Artikel-Dede-1623.pdf.Diakses pada tanggal 20 Januari 2014.

Redhana, I. W., Setiono, K., Permanasari, A., Liliasari. 2008. Program for Critical Thinking Skill Teaching and Learning : Excellences and Problems in ITS Implementation. PROCEEDING The Second International Seminar on Science Education: 623 -629.

Sugiyono. 2010. Metode Penelitian Pendidikan pendekatan Kuantitatif, Kualitatif, dan $R \& D$. Bandung : Alfabeta.

Suardana, I. W. 2008. Teaching and Learning analysis of basic Chemistry In Developing Teaching and Learning Of CriticalnThinking Skils PROCEEDING The Second International Seminar on Science Education: 551-556.

Sunyoto dan Maryatun, S. 2006. Optimalisasi Pembelajaran Kimia Kelas XI Semester I SMA Swadhipa Natar Melalui Penerapan Metode Eksperimen Berwawasan Lingkungan. Prosiding Seminar Hasil Penelitian Bidang Kependidikan BKS PTN Wilayah Barat Di Bandar Lampung Tanggal 30-31 Mei 2006 FKIP Unila Bandar Lampung: 63-72.

Tatang, M. 2008. Pembelajaran Analitik Sintetik untuk Meningkatkan Kemampuan Berpikir Kritis dan Mreatif matematika Siswa Sekolah Menengah Atas. Ringkaan disertai. UPI.

Taufik, A. 2011. Pengembangan LKS Model Probing untuk Meningkatkan Hasil Belajar Kimia Ditinjau Dari inat Belajar Siswa Kelas XII IPA SMAN I Praya.Tesis. Program Pascasarjana Universitas Mataram.

Yuliani, H., Sunarno,W., dan Suparmi. 2012. Pembelajaran fisika dengan keterampilan proses dengan metode eksperimen dan demonstrasi ditinjau dari sikap ilmiah dan kemampuan analisis. Jurnal inkuiri.http://jurnal. pasca.uns.ac.id. Diakses pada tanggal 20 januari 2014. 